\title{
U.S. President Joe Biden's Foreign Policy towards the Gulf ${ }^{*}$
}

\author{
Hassan Hamdan AlAlkim \\ American University of Ras AlKhaimah, Ras AlKhaimah, United Arab of Emirates \\ Email:hhalkim@aurak.ac.ae
}

How to cite this paper: AlAlkim, H. H. (2021). U.S. President Joe Biden's Foreign Policy towards the Gulf. Open Journal of Political Science, 11, 378-401. https://doi.org/10.4236/ojps.2021.113026

Received: April 5, 2021

Accepted: June 4, 2021

Published: June 7, 2021

Copyright $\odot 2021$ by author(s) and Scientific Research Publishing Inc. This work is licensed under the Creative Commons Attribution International License (CC BY 4.0).

http://creativecommons.org/licenses/by/4.0/

\begin{abstract}
U.S. President Joe Biden, with long experience in foreign policy, is likely to understand that contemporary Middle East issues are interrelated. Focusing on Biden's first 100 days in office, this study used a comparative analysis approach with the aim of assessing the significance of Biden's foreign policy, how a renewed American commitment to global engagement might help in addressing Gulf issues, and to determine Biden's priorities in the Gulf and how he is likely to deal with U.S. Gulf allies on issues such as human rights, the Yemen war, and the Iranian nuclear deal. It appears that Biden intends the U.S. to play a more active role globally but with an understanding that the U.S. will be less inclined to pursue unilateral action or use force to deal with foreign policy challenges. Only with the collaboration of allies in the region and around the world will the U.S. be able to pursue the multiple initiatives needed to address the legitimate security concerns of the Arab Gulf states while advancing human rights.
\end{abstract}

\section{Keywords}

Biden, US, Foreign Policy, Middle East, \& Gulf

\section{Introduction}

States view their actions in foreign policy through the lens of national interests, but the choices they make depend on leaders' perceptions and how they choose to define and pursue national interests under different circumstances. U.S. for-

${ }^{*}$ Both sides of the water channel dividing the Arab Gulf countries from Iran dispute the name in terms of ethnic, cultural, and historical factors. Most western and Persian sources, with few exceptions, use the Persian Gulf whereas Arab literature uses the Arab Gulf. Unfortunately, the differences between both sides are so deep that they prevent any objective discussion to reach a mutual agreement on the name; therefore, the author of this paper decided to use the Gulf to avoid any misunderstanding. The use of the "Arab Gulf" on the Russian Foreign Ministry twitter account instigated an official Iranian protest, reported on Arabic.cnn.com, Feb. 8, 2021. 
eign policy has always oscillated between globalization and retrenchment (Nye, 2020: p. 210). According to Hans Morgenthau, "the state has no right to let its moral disapprobation of the infringement of liberty get in the way of successful political action". He goes on to say that "realism considers prudence to be the supreme virtue in politics" (Morgenthau, 1973: p. 10). However, the organising principle of U.S. Gulf policy has morphed into containing Iran regardless of the destabilizing effects of this policy on the region (Parsi, 2021: p. 3).

The election of Democratic Party candidate Joe Biden as U.S. President has brought new thinking to U.S. foreign policy towards the Gulf, marking a departure from his predecessors. Biden has spoken of a return in foreign policy making to more structured and routine foreign policy channels, ensuring a foreign policy that balances American values and interests. This new foreign policy approach will not, however, reduce the importance of the Gulf region in U.S. strategy but will recalibrate relations. The organizing principles of U.S. Gulf policy will continue to centre around preventing nuclear proliferation, de-escalating tensions and reducing the arms race, encouraging constructive regional engagement among regional states, containing radical Islamist ideology, normalizing relations with Israel, and blocking Russian and Chinese influence.

This study aimed to analyse prospects for Biden's "new" foreign policy towards the Gulf region. The research questions included the following:

1) What will Joe Biden's priorities be in the Gulf?

2) How will he differ from his predecessor in dealing with U.S. Gulf allies?

3) Will Biden pursue his campaign promises for a more transparent relationship with Gulf allies, re-engagement with Iran, and stopping the war in Yemen?

The study used a comparative analysis approach in investigating the dynamics of U.S.-Gulf relations, comparing Biden's proposed approach to the region with the approaches of prior U.S. presidential administrations. The study was based on the hypothesis that the Biden administration would recalibrate U.S. relations with Gulf states, shifting from a focus on oil and security to a greater reliance on soft power, for example, through increasing economic, trade, and financial investments, and through giving higher priority to democratization and human rights. It has been assumed that Biden, having endured profound personal grief twice, would be less inclined to depend on military means and rely more on soft power in foreign policy. Having had long experience in foreign policy, Biden is likely to understand that contemporary Middle East issues are intricately interwoven and that, as in a type of domino theory, bringing one issue to a satisfactory end will lead to other issues falling into line. Such issues in the region include Gulf security, the Iran nuclear program, the Yemen War, and human rights, with Iran being at the epicentre of this complexity. The paper is concerned only with issues related directly to the Gulf region, with a focus on the dynamics of U.S. foreign policy in the Gulf region, the tumultuous nature of the region, the Iran nuclear deal, and the war in Yemen. The paper has relied mainly on secondary sources to do the comparative analysis and draw the conclusion. 


\section{U.S. Foreign Policy Dynamics in Dealing with the Gulf}

The relationship between successive American administrations and the Arab Gulf countries has been dynamic despite two factors that have consistently shaped American policy in the Gulf region. The region has remained important to the U.S. throughout multiple administrations because of its proven energy reserves and the extent to which countries of the region have become major arms importers. In 2018, the Gulf countries had combined proven oil reserves of 803 billion barrels, amounting to 50 percent of the world's proven oil reserves ${ }^{1}$, and combined proven natural gas reserves of 72 trillion cubic meter $(\mathrm{tcm})$, accounting for 36.5 percent of the world's proven natural gas reserves ${ }^{2}$. Despite a decline in U.S. dependence on Gulf oil, which covers only 15 percent of its needs due to increased domestic oil production, the U.S. in 2018 spent roughly $\$ 81$ billion to prevent interruption of the global oil supply (Securing America's Future Energy, 2018).

To ensure regional security, U.S. Presidents since the late 1960s have issued multiple doctrines reiterating U.S. commitment to Gulf security. U.S. administrations, starting with Nixon's Twin Pillar policy in 1969, have emphasized regional security cooperation between Iran and Saudi Arabia, apart from the Carter Doctrine with its focus on the importance of the "Persian" Gulf to U.S. interests. Over the years, Republican Presidents especially have had close relations with Gulf monarchies and have been attentive to their security needs. Successive American administrations have delivered highly sophisticated U.S. weapons to their Arab Gulf allies. Different U.S. administrations have sought to use arms sales to bolster their partners' capabilities to advance major U.S. regional security policy priorities, including countering terrorism, ensuring an uninterrupted flow of oil, and countering Iran (Congressional Research Service, 2020). Saudi arms imports increased by 130 percent over the years 2015-2019, accounting for 12 percent of global arms imports (Stockholm International Peace Research Institute (SIPRI), 2020). The Obama administration, for example, despite its concerns for democracy and human rights, offered Saudi Arabia more than \$115 billion in weapons, more than any administration in the preceding 71 years (Bayoumy, 2016). President Donald Trump and his Secretary of State, Mike Pompeo, treated Saudi Arabia and its Crown Prince Mohamed bin Salman (MBS) as a major ally in their campaign to cripple Iran through sanctions. To that end, "Pompeo used emergency powers to sidestep Congress to keep arms supplies flowing to the Gulf” (Borger \& Wintour, 2021).

Despite this consistent attention by American presidential administrations to the importance of the Gulf region to U.S. interests, the vacillation between glo-

${ }^{1}$ Gulf-proven oil reserves in 2018 were; Saudi Arabia 267.8, Iran 155.6, Iraq 145.02, Kuwait 101.5, UAE 97.8, Qatar 25.2, and Oman 5.5 billion barrels. Data compiled from: OPEC Annual Statistical Bulletin 2019, King Abdullah Petroleum Studies and Research Center (KAPSARC), 2018; Data Insight, 2018 Annual Proven Crude Oil Reserves, December 2018; and usatoday.com, May 22, 2019.

${ }^{2}$ Gulf-proven natural gas reserves in 2018 were; Iran 31.9 trillion cubic meters ( $\left.\mathrm{tcm}\right)$, Qatar $24.7 \mathrm{tcm}$, UAE $5.9 \mathrm{tcm}$, Saudi Arabia $5.9 \mathrm{tcm}$, and Iraq $3.6 \mathrm{tcm}$. Data compiled from: Nsenergybusiness.com/features/largest-natural-gas-reserves-middle-east, 29 November 2019. 
balization and retrenchment has resulted in a less than consistent approach to the region. U.S. Gulf policy has reflected shortcomings in the U.S.'s global power outreach. According to Nye, Presidents Roosevelt, Truman and Eisenhower, in learning from the experiences of the 1930s, shared a belief that isolationism was a mistake, and engineered a shift in U.S. foreign policy from isolation to globalization. A subsequent isolationist orientation was evident in Trump's retreat from international organizations, strained relations with European allies and China, withdrawal from the Iran nuclear deal, and abandoning the advancement of democratization and human rights. Nye argues that Trump's retrenchment policy clearly revealed that American foreign policy had been shaped from within by the rise of populist politics that narrowed its moral vision, which had greater effects than changing power relationships among major countries (Nye 2020: p. 206). Trump successfully linked white resentment over the increasing visibility and influence of racial minorities to foreign policy through blaming economic problems on "bad trade deals with countries like Mexico and China and on immigrants competing for jobs" (Nye, 2020: p. 20). Trump's retreat from globalization to isolation reflected a foreign policy shaped by his inexperience in world affairs, his narcissism, the adulation received from his nationalistic supporters, and his acceptance of fundamentalist evangelical religious doctrines (Inbari et al., 2021) ${ }^{3}$ embraced by a major component of his political base.

A lack of respect for other cultures and religions by the U.S. has arguably caused administrative rifts and weakened soft power, undercutting national interests (Nye, 2020: p. 50). Furthermore, Trump's behaviour as President led to instability in the U.S. government, with turnover in the Trump administration at 92 percent as of 20 January 2021, the highest since President Ronald Reagan's administration (Tenpas, 2021). Finally, through imposing sanctions on noncompliant countries while selling sophisticated arms to U.S. allies in the region, Trump exacerbated "the very factors that have caused regional instability" (Parsi, 2021: p. 3). It has been contended that the American decision to scale down their engagement in the Middle East has paved the way for another actor's resurgence (Wechsler, 2019).

Biden came to power in a divided country, with over 400,000 deaths from the coronavirus (COVID-19) pandemic (Wehner, 2021) and a crippled economy with the worst jobs record in modern U.S. history at 6.9 percent unemployment (Bureau of Labor Statistics, 2021). There were 3 million fewer jobs in the U.S. at the end of Trump's term than on Trump's Inauguration Day on 20 January 2017 (Burns, 2021). Biden, with more than 38 years of experience in government, enjoys the respect of members of Congress from both parties. President Barak Obama (2009-2016) relied on him as Vice President to advance deals with Con${ }^{3}$ For more information on the evangelical Christians, see Inbari, Motti, Bumin, Kirill, \& Byrd, M. Why do evangelicals support Israel? Published online by Cambridge University Press: 14 January 2020,

https://www.cambridge.org/core/journals/politics-and-religion/article/why-do-evangelicals-supportisrael/F8AB8C41F0B019FD8413A30EF218EBE4. Politics and Religion, 14 (1), 1-36. DOI: https://doi.org/10.1017/S175504831900052X. 
gress. Biden has experienced divided government not only in terms of an obstructive Senate but also through his exposure to the uncooperative attitude of the current Minority Leader, Mitch McConnell, (Obama, 2020; p. 382), who is likely to wish to cripple the Biden presidency generally and to impede Biden's efforts specifically to reform American foreign policy (Sargent, 2020). To achieve his vision, Biden has been conservative in drawing his Cabinet members mainly from a centrist stream, avoiding the appointment of prominent or progressive figures, and has relied on professionals with previous experience of government portfolios in both the Clinton and Obama administrations, with diverse ethnic backgrounds, and with whom he feels comfortable. Nevertheless, Biden's relationship with Republicans in Congress so far has not been cooperative. His pick of Neera Tanden, who heads the Centre for American Progress, to lead the White House Management and Budget Office, led to a contentious confirmation process (Karni et al., 2021), and the nominee was obliged to withdraw. Biden's failure to draw bipartisan support for his $\$ 1.9$ trillion economic rescue plan reflects the rift in Congress and might push Biden further towards the progressive left.

Biden will be weakened by Trump's legacy of a polarized society, a delegitimized American democratic process, and multiple foreign policy blunders. Biden understands that non-engagement with global issues is not a feasible option and that insularity is not possible. He took office facing two global power shifts. One is a horizontal shift from West to East, with the rebirth of Asia as a major power centre, seen in the growing influence of Japan, China, India, and other countries of Southeast Asia (Nye, 2020: p. 192). The sources of power have shifted, with less emphasis on military power and more on economic power. China has emerged as a major and rapidly developing economic power whose military power is also developing, forming a key component in the shift in the balance of power from the West to the East. China has for the first time surpassed the U.S. as the top destination for foreign investment. Foreign investment in the U.S. fell by 49 percent in 2020 to $\$ 134$ billion whereas China recorded a slight 4 percent rise to reach $\$ 163$ billion (Paton, 2021). The Regional Comprehensive Economic Partnership announced on 15 November 2020 and signed by members of the Association of Southeast Asian Nations (ASEAN) and five regional partners including China and Japan, will shape subsequent global economics and politics and will require renewed efforts by the U.S. to advance its economic and security goals. As he moves to address these challenges to U.S. leadership, human rights defenders, however, have expressed concerns that Biden might be more accommodating with China than his predecessor (Beech, 2020).

Biden has promised a change of policy in dealing with China. U.S. Secretary of State Antony Blinken has described China as "the only country with the economic, diplomatic, military, and technological power to seriously challenge the stable and open international system" (Usher, 2021b). Biden is working on rebuilding ties with frustrated allies and assembling a united front against 
China (Jakes et al., 2021). On 20 February 2021, Biden sought to rally European allies in Munich against China by saying that global democracies faced a defining moment in their contest with authoritarianism (Kempe, 2021), which was followed on 11 March with the Quad Summit Conference, as part of Biden's plan to contain China (Lendon, 2021). He dispatched Blinken and Secretary of Defence Lloyd Austin to both Japan and South Korea to reiterate U.S. commitment to South Pacific security. These officials expressed disapproval over what they called "coercion" and "destabilizing actions" by China's military. The U.S. State Department threatened to impose financial sanctions on 24 Chinese officials for undermining Hong Kong's democratic process (Barnes, 2021), setting a confrontational tone ahead of Blinken's meetings with two top Chinese officials on 19 March in Alaska (Barnes, 2021). However, any U.S. policy must factor in China's role as the leading trading partner for most of America's key partners.

A second global power shift has occurred in relation to a vertical power shift, which refers to the increase in non-state actors and forces such as Wikileaks, multi-national corporations, non-governmental organizations (NGOs), technological complexity, terrorism, cybercrime, pandemics, financial instability, and climate change (Nye, 2020: pp. 199-205). It has been alleged that Russian President Vladimir Putin authorized extensive efforts to interfere in the U.S. election to reduce Biden's chances of success (Barnes, 2021). Russian intervention in the 2016 U.S. election and threats of another Russian cyberattack in 2020 (O’Sullivan \& Cohen, 2020) provide evidence that governments are prepared to use non-state tools in attempts to destabilize other countries. When he was Secretary of State, Pompeo publicly confirmed that Russia was behind the massive cyber spy breach against the U.S. federal government and private sector (Nakashima \& Dawsey, 2020). Biden, in his first foreign policy speech, was firm on Russia. He promised the U.S. "would no longer turn a blind eye to Russia's aggressive actions like meddling in U.S. elections, launching cyber-attacks on American companies and infringing the rights of its own citizens" (Porterfield, 2021). Biden, in an interview with ABC on 17 March 2021, called Putin a killer and threatened to retaliate (Troianovski, 2021). Blinken has promised a harder line in response to Russian cyber-attacks and election meddling (Usher, 2021b). Such action would require the new administration to allocate further resources and invest more in cyber security and artificial intelligence to protect national security.

Biden's policy towards the U.S.'s Arab Gulf allies will be recalibrated to weigh American values and interests more explicitly against the interests of the Arab Gulf states. He has elected to pursue an agenda that includes a return to a focus on globalization but with an understanding that the U.S. will be less inclined to pursue unilateral action or use force to deal with foreign policy challenges. Biden has promised an engaged foreign policy that operates on a democratic-progressive basis, distancing himself from his predecessor and his conservative-isolationist orientation that appealed to the extreme American right. It would appear that, 
despite elements of the Trump legacy that may impede him, Biden will seek to radically diverge from Trump's foreign policy approach while pursuing a foreign policy closer to that of the Clinton-Obama administrations, as manifested in his team selection. However, his foreign policy is likely to differ from his democratic predecessors in giving more weight to American values. Biden's foreign policy is likely to be more responsive towards the concerns of progressive democrats who voted for him but who otherwise refrained from voting for Hillary Clinton in 2016. Biden is expected to put more emphasis on democratization and human rights. Therefore, in recalibrating relations with Gulf countries through reaffirming a commitment to American values and not relying exclusively on the value of arms sales or the importance of access to oil, Biden can be expected to be less likely to use force in foreign policy. As observed by former President Obama, Biden has some reservations concerning the role of U.S. military generals in foreign policy making. Biden, for example, expressed concern over sending an additional 20,000 U.S. troops to Afghanistan. Obama wrote that Biden gripped his arm, saying "listen to me, boss, maybe I've been around this town for too long, but one thing I know is when these generals are trying to box in a new president". Obama added that Biden got closer and whispered, "don't let them jam you" (Obama, 2020: pp. 318-319).

The U.S. will continue playing a leading global role, at least for the foreseeable future. However, the new and more subtle American foreign policy will be based on the principle of engagement with allies and partners, and continued dialogue with certain emerging independent regional/global actors. Biden has repeatedly asserted the need for global re-engagement in dealing with Gulf contemporary issues. The Biden administration is more likely to pursue a collectively bipartisan foreign policy approach that is based on a critical macro-level assessment of U.S. national interests, as opposed to more narrowly focused, individualistic, or party interests. This approach was foreshadowed in his electoral campaign where he argued for ending the deadlock in U.S.-Iran relations, stopping carte-blanche support of Arab Gulf allies, limiting arms sales to the region, exerting pressure to end the Yemen war, and advancing human rights in the region.

\section{The Challenge of Promoting Stability in the Turbulent Gulf Region ${ }^{4}$}

The Gulf region remains the most dangerously deinstitutionalized region in the world (Parsi, 2021), deeply challenged by regional tensions (Mezran \& Vavelli, 2019: p. 17). Interstate military rivalries between Gulf states since the 1980s (Dorsey, 2021) have undermined regional stability, fuelled extremists, encouraged sectarian cleavages, and turned the region into the most volatile part of the world (Dorsey, 2017). The Saudi-led $21^{\text {st }}$ century version of autocracy is designed to fortify absolute rule to ensure the survival of these regimes at whatever cost (Dorsey, 2021). That system embraces social and economic reform but de${ }^{4}$ For more details see AlAlkim and Hassan (1994). The GCC STATES IN AN UNSTABLE WORLD. Saqi Books. pp. 101-124. 
nies basic political freedoms and human rights. The retreat of regional and international powers from the region "increases the possibilities of small states' external extraction and allocation of resources for the purpose of engaging in the international arena" (Abozaid, 2020: p. 320). The establishment of the Gulf Cooperation Council (GCC) in May 1981 among the conservative Arab Gulf countries was intended to ensure security but failed to adopt a conflict-resolution mechanism (AlAlkim, 1994). The GCC could not prevent internal disputes, which resulted in a boycott of Qatar from 2017 to 2020 by Saudi Arabia, the UAE, and Bahrain. That dispute was finally resolved during the Al-Ula Summit in Saudi Arabia in December 2020, a move welcomed by Blinken. However, the resolution of the dispute did not include a substantive settlement of differences over Qatar's relations with Iran and Turkey, its support for the Muslim Brotherhood, and the headquartering of the news agency Al-Jazeera in Qatar. The Saudi decision for rapprochement came about because of the Trump administration's determination to conclude with a foreign policy success and new Saudi policy priorities concerning a need to send positive messages to the new administration in Washington.

Intra-Gulf relations reflect the pendulum of U.S.-Iran relations, which oscillate from belligerency to benevolence. Once Washington, under Trump, showed a disinclination to become involved in armed confrontation with Tehran, the Saudis and the Emiratis very reluctantly acquiesced in pursuing a policy of re-engagement with Iran (Parsi, 2021: p. 15). The Trump administration's unwillingness to retaliate in response to the shooting down of an American spy plan and a drone attack on Saudi refineries in Abqaiq and Khurais resulted in both the Saudis and the Emiratis reaching out to Iran through intermediaries. Riyadh stepped up direct talks with Yemen's Houthi rebels (Strobel, 2020) while Abu Dhabi decided in October 2020 to withdraw forces from Yemen. The UAE opened direct talks with Iran over maritime security ${ }^{5}$ and released $\$ 700$ million in frozen funds to Iran $^{6}$. Iran, in turn, floated a peace plan based on a mutual Iranian-Saudi pledge of non-aggression (Parsi, 2021: p. 14). Javad Zarif, Iranian Foreign Minister, hinted at a new approach and acknowledged missed opportunities between Iran and Saudi Arabia (Ghantous, 2021). Saudi-Iran proxy wars and Turkey's ability to partner with different players in the region (e.g., Qatar, Libya, and Somalia) have allowed Ankara to expand its network of allies in the Arab world (Mezran \& Vavelli, 2019: p. 10). Containing this growing influence of Turkey may be another factor prompting Saudi Arabia and the UAE to pursue overtures to Iran. Abdulla bin Zayed, UAE's Foreign Minister, reiterated, in a phone conversation with Robert Malley, U.S. special envoy to Iran, the UAE's commitment to working with the Biden administration to reduce tensions in the region. Despite official Iranian hostile rhetoric, officials privately concede that ${ }^{5}$ Reuters (2019, July 30). Rivals Iran and UAE to hold maritime security talks. Reuters. https://www.reuters.com/article/us-mideast-iran-emirates-idUSKCN1UP184.

${ }^{6}$ Middle East Monitor (2019, October 21). UAE released $\$ 700$ million in frozen funds to Iran. Middle East Monitor.

https://www.middleeastmonitor.com/20191021-uae-releases-700-million-of-iranian-funds/ 
an inclusive security arrangement will not succeed without the approval and engagement of the U.S. (Parsi, 2021: p. 17).

The new transparent and more balanced foreign policy operating within the Washington-Riyadh relationship is one of the most conspicuous features of the new American administration. The new foreign policy involves the use of more diplomatic initiatives to break out of the current cycle of conflict and escalation that is too costly for the U.S. and for the region's people (Kaye et al., 2021). Biden has pointed out that the relationship should advance U.S. interests as well as be respectful of the values that "we bring to that partnership" (Turak, 2021). Biden wants to ensure that the alliance reflects U.S. values and interests and not just those of the Saudis (Ross \& Satloff, 2021: p. 3). Specifically, Biden promised to reverse controversial foreign policy issues (e.g., freezing arms sales to Gulf allies and delisting Houthi militia as a terrorist group), and has spoken of ending the deadlock in U.S.-Iran relations, stopping unconditional support of Arab Gulf allies, limiting arms sales to the region, exerting pressure to end the Yemen war, and advancing human rights in the region. In recalibrating the relationship with Saudi Arabia, he intends to downgrade connections with MBS because of the latter's ruthless policies and has emphasized an intention to engage with King Salman (Fabian et al., 2021). The new administration is adopting a more structured approach to the relationship with Saudi Arabia through employing routine channels, demonstrated through Biden speaking to King Salman on 25 February 2021 while MBS, the de facto ruler, received a call from Lloyd Austin III, the U.S Defence Secretary earlier on 18 February. However, foreign policy is not just about "virtue signalling"; it is also about advancing interests (Haass, 2021), which explains why the U.S. does not wish to cut its ties with the Kingdom. Washington and Riyadh need each other in ways that go far beyond the old formula of "oil for security", although oil market stability remains pivotal (Ross \& Satloff, 2021: p. 3). Washington needs the Saudis to achieve U.S. strategic aims in the region, ranging from countering Iran, providing support for counterterrorism, ending the war in Yemen, helping Arab countries financially, normalizing Arab-Israel relations, to discrediting radical Islamist ideologies (Ross \& Satloff, 2021: pp. 3-5). Biden, although reiterating U.S. support for protecting Saudi Arabia from Houthi rockets, announced an end to U.S. support for the Saudi-led offensive operation in Yemen, which he called a "humanitarian and strategic catastrophe" (Crowley, 2021). This preference for more balanced and transparent relations is also clear in Biden's making public the intelligence report revealing MBS's approval of the operation that led to the killing of the journalist Jamal Khashoggi; but Biden, on the advice of his national security team, decided not to penalize the Crown Prince because the cost was too high (Sanger, 2021). Blinken justified the decision by saying that the "relationship with Saudi Arabia is bigger than any one individual" (Shesgreen, 2021).

The GCC is not a suitable framework for achieving regional stability arrangements since it is paralyzed by internal conflicts and its primary foundational 
purpose was to shield against threats emanating from Iran and Iraq. Any new regional structure should be based on a $6+3$ formula (an arrangement that would include the six GCC countries plus Iraq, Iran, and Yemen) (AlAlkim, 1994: p. 164). Such a framework would place an emphasis on soft security arrangements, focusing on disaster relief cooperation, humanitarian assistance, drug trafficking, pandemics, maritime security, pilgrimage security, and climate change, but also involving hard security arrangements, focusing on transparency in defence expenditures, weapon acquisitions, foreign bases, and weapons of mass destruction (Parsi, 2021: pp. 17-19). Given that the new U.S. administration still has many options, embracing such a framework for defusing tensions in the Gulf region could be an important component of its renewed commitment to principled international re-engagement. Biden's presidency may put an end to many years of enmity and "herald a new start for Saudi-Iran relations" (Wintour, 2021). The Biden administration is expected to prioritize diplomacy and act collectively with the permanent members of the United Nations (UN) Security Council and major Asian powers, to encourage institutionalizing intra-Gulf dialogue for the creation of long-lasting security arrangements. U.S. National Security Advisor Jake Sullivan and Deputy Assistant Secretary of State for Arabian Peninsula Affairs Daniel Benaim believe that there could be a new vision emerging concerning U.S. Gulf policy, focusing on "fostering much-needed intra-regional dialogue", with an emphasis on diplomacy (Parsi, 2021: p. 3). Small Arab Gulf states, however, are reluctant to support this region-focused approach for fear of Saudi dominance or potential entanglement in inclusive security arrangements. They prefer the continuation of Pax Americana, with the U.S. remaining prepared to ensure their security (Parsi, 2021: pp. 11-12).

Maintaining regional security and stability will require the Gulf countries to engage in constructive dialogue. In an unofficial "backchannel" initiative, Saudi and Iranian writers, Abdulaziz Sager and Hossein Mousavian, asserted in a joint article that "both countries perceive the other as seeking to dominate the region, with Riyadh convinced that Iran is trying to encircle the Kingdom with its allied proxy supporters while Tehran views Saudi Arabia as in alliance with the U.S. to undermine the Islamic Republic" (Sager \& Mousavian, 2021). They urged the two sides to agree on a set of principles around non-interference, rejection of violence, respect for religious minorities, and abandonment of the use of proxy forces (Ghantous, 2021).

Iranian behavior in the region has exacerbated instability. The relations between Iran and the Arab Gulf states have moved from détente to belligerency with the success of the Iranian revolution in February 1979. The mistrust grew with the new Iranian leadership calling for the export of the revolution to the neighbouring countries that culminated in eight years of Iran's war with Iraq. Sectarian differences inspired direct interference in the affairs of the regional countries, especially Saudi Arabia, Bahrain, Kuwait and Iraq post Saddam. Iran's decision to reinvigorate its nuclear program for peaceful means intensified re- 
gional turbulence and draw other actors to the scene. The small Arab Gulf states became further alienated from and threatened by Iran, contributing to a regional arms race and opening a new chapter in these states' relations with Israel. Israel started looking at the Iranian nuclear program as a direct threat to its national security and led to its direct involvement to limit Iran's capability. The region became more internationally polarized with Russia and China seizing the opportunity to benefit from Iran's isolation by opening new venues of collaboration with Iran. The U.S. and its European allies looked at the Iranian nuclear program as a breach of the nuclear non-proliferation treaty of 1968 and amassed international support for a series of measures to force Iran to curtail its nuclear development. The pressure exerted by the international community led by the U.S. culminated in the conclusion of a deal on July 14, 2015 between Iran and the five Permanent Members of the United Nations Security Council $(5+1)$ plus Germany. The deal, however, was short-lived with Donald Trump's unilateral decision to withdraw from the deal. The development of the Iranian nuclear program and the outcomes associated with it has intensified regional conflicts, promoted a continuing arms race, and enhanced sectarian cleavages and instability. The intra-regional relations have further deteriorated with Iran embarking on proxy wars in Yemen, Syria, and Lebanon. Concern about Iran has also caused a fundamental regional shift in alliances, with Israel becoming an integral part of regional security arrangements involving Saudi Arabia, the UAE, and Israel. Joe Biden with long experience in regional politics, aware that Iran today represents a fundamental challenge to regional security, is adamant on bringing Iran back to the negotiating table and ultimately reactivating the Iran nuclear deal.

\section{The Iran Nuclear Deal}

The success of the Islamic revolution in Iran, in February 1979, was a historical turning point in Iranian-American relations, with the U.S., on 7 April 1980, deciding to cut off diplomatic relations with Iran following the hostage crisis ${ }^{7}$. The Carter Doctrine had designated the "Persian" Gulf as vital to U.S. interests. As a result, after more than four decades of sanctions and strained relations apart from a short period during the Obama administration, Iranian economic and military power has been crippled, with the U.S. remaining primarily focused on containing Iranian nuclear capability.

The Iranian nuclear program began in 1957 during the reign of Shah Mohamad Reza Pahlavi, who signed a nuclear agreement with the U.S. The program developed under American supervision until the Islamic Revolution in Iran in 1979 resulted in the program being terminated as a foreign concession that violated national sovereignty. A religious fatwa was issued by Ayatollah Khomeini ${ }^{7}$ Relations between Iran and the U.S. deteriorated, after the U.S. agreed to receive the deposed Shah Mohamed Reda Pahlavi for cancer treatment. A mob of Iranian students besieged the American embassy on 4 November 1979 and detained 52 American embassy staff employees for 444 days. On 7 April 1980, President Jimmy Carter decided to severe diplomatic relations. https://ar.wikipedia.org/wiki/. 
prohibiting the use of nuclear power, claiming that "nuclear weapons are an act of evil and not Islamic". The Iraq-Iran war (1980-1988) and the use of ballistic missiles against Iranian cities led to a reversal of the Iranian decision on nuclear weapons and a move to revive its nuclear program to achieve a regional balance of power. Since that time, Iran has worked to develop its nuclear program to an advanced stage ${ }^{8}$. In this context, Iran is unwilling to make concessions on its nuclear program without obtaining relief from economic sanctions ${ }^{9}$.

The U.S. has worked multilaterally through the UN to apply sanctions in relation to Iran's nuclear program, with the UN Security Council issuing various security council resolutions (SCRs) in this case: UNSCR 1737 (2006), UNSCR 1747 (2007), UNSCR 1803 (2008), and UNSCR 1929 (2020) (U.S. Department of State, 2021). Obama in 2015 led a $5+1$ coalition that obtained agreement on limiting Iran's nuclear capability, but this was later repudiated by Trump. The Obama-led agreement was criticized by Israel, Saudi Arabia, and the UAE, who expressed frustration at Obama's decision to negotiate a nuclear deal with Iran without consulting them. MBS chided Obama for turning his back on his Arab allies in the Gulf and, in an interview with Atlantic, he contended that Obama's negotiations with Iran while maintaining the Saudi alliance amounted to a betrayal (Hope \& Scheck, 2020: p. 147). Both Saudi Arabia and the UAE perceived the Joint Comprehensive Plan of Action (JCPOA) in relation to Iran's nuclear capability as a measure in which the U.S. abandoned its role as a counterbalance to Iranian power. Trump, in May 2018, decided to withdraw from the agreement, enforcing tougher measures against Iran and any country or company that dealt with it.

Trump's withdrawal from the JCPOA led to an escalation in the U.S.'s military involvement in the Gulf, and his introduction of tougher sanctions resulted in Iran changing direction concerning uranium enrichment. Escalating tension led Iran to move its nuclear enrichment facility to mountain foothills, south of Natanz, approximately 140 miles south of Tehran, to protect it against possible American or Israeli attack. Further construction was prompted following an explosion in July 2020 that destroyed a centrifuge assembly facility (Koetti, 2020). The Iranian government's commitment to this project appears to have been strengthened by the assassinations of the Revolutionary Guard Commander, Qassem Soleimani, in January 2020 and of Mohsen Fakhri Zadeh, the leading Iranian nuclear scientist, in November 2020. Zadeh was described by the U.S. and Israel as the force behind Iran's covert push for nuclear weapon (Fassihi et al., 2020) and Israeli leader Benjamin Netanyahu referred to him at the UN General Assembly. Iran began to violate the terms of the nuclear deal after Trump's withdrawal and the re-imposition of sanctions. It informed the International Atomic Energy Agency (IAEA) of its plan to enrich uranium to a purity ${ }^{8}$ In December 2020, Iran announced plans to enrich uranium to $20 \%$ in response to the assassination of Dr. Fakhrozadeh. Sources attribute the killing to Israel.

${ }^{9}$ The Supreme Leader of the revolution, Ayatollah Ali Khamenei. [Recorded Public Speech], YouTube, 8 January 2021. 
of up to 20 percent despite being required under the deal to keep enrichment below 4 percent (Gardner, 2021). A confidential report to the IAEA indicated that Iran had produced uranium metal, a component for the core of a nuclear bomb (Murphy, 2021). According to U.S. State Department Spokesperson Ned Price, "there is a challenge we have to tackle immediately, ensuring Iran is not in a position to develop a nuclear weapon" (Price, 2021).

Sullivan has indicated that the Biden administration would like to re-engage with Iran in the $5+1$ nuclear deal (Sink, 2021). However, any such re-engagement is conditional on Iran's adherence to the JCPOA, before any communications between Biden and Iranian President Hassan Rouhani can occur. On 10 March 2021, Blinken reiterated the U.S. demand for Iran's adherence to the JCPOA before Washington could initiate negotiating a better deal covering other contentious and difficult issues. The U.S. is looking to include Iran's missile arsenal and its precision-guided weapons in any future negotiations. Biden has named Robert Malley, the architect of the 2015 nuclear deal, as a special envoy for Iran, and tasked him with revamping and enhancing diplomacy towards Iran, to bring about a "stronger and longer" nuclear deal than the JCPOA. Biden has also selected William Burns, who led a U.S. delegation in secret talks with Iran, as CIA Director. The Biden administration is under time pressure, wanting to bring Iran back to the negotiation table before the next Iranian Presidential election on June $18^{\text {th }}, 2021$. The hawks in both Iranian and Israeli administrations are pushing back against any breakthrough in the negotiations. The U.S. State Department Spokesman, Ned Price, called on Iran to return to full compliance with its commitment for the JCPOA. He reiterated the U.S. commitment to reciprocate, observing that "we are prepared to walk the path of diplomacy if they return to full compliance" (Haboush, 2021). Sources allege that Biden's team has already started talks with Iran on the U.S. desire to return to the nuclear deal. ${ }^{10}$ Biden's Administration informed Israel of its approach, with Yossi Cohen, the Mossad Director, visiting Washington for discussions of this issue (Al Sawafi, 2021: p. 22).

The U.S.'s European allies, Israel, and the GCC countries would like to include Iran's missile capability and Iran's influence in the Middle East in any future negotiations. In general, the GCC states would like to be consulted and engaged in any new negotiations over the Iran nuclear deal. A successful re-engagement in the $5+1$ nuclear deal could pave the way for a new regional detente and could ultimately bring an end to the war in Yemen if Iran will re-commit to the agreement and the U.S. fulfils its obligations towards its allies, the GCC countries and Israel. Jake Sullivan clearly expressed the U.S. intention to put Iran's nuclear program "back into a box" and then deal with other Iranian problematic activities in the Middle East (Lee, 2021). Joe Biden, in an interview with CBS News, said he will not lift economic sanctions to get Iran back to the negotiating table. Rather, Iran must stop enriching uranium first (Salama, 2021b). Iran,

${ }^{10}$ The Times of Israel (16 January 2021).

https://www.timesofisrael.com/report-biden-team-already-holding-talks-with-iran-on-us-return-tonuclear-deal/. 
on the other hand, would not accept preconditions for reviving nuclear deal. Iranian Supreme Leader Ayatollah Ali Khamenei has been quoted as saying: "if [the U.S.] wants Iran to return to its commitments, it must lift all sanctions in practice"11. The Qatari Foreign Minister has indicated that Qatar was prepared to mediate between the two parties because of the effects of ongoing tension on regional stability and that Qatar was striving to deescalate such tension through fostering an effective political and diplomatic process to revive the nuclear agreement $t^{12}$. While pursuing a firm line, the Biden administration has also been conciliatory, and has eased financial restrictions, allowing Iranian oil sales to provide backing for International Monetary Fund lending to Tehran, and has lifted some sanctions that have stymied international efforts to bring aid in the fight against the COVID-19 pandemic into Iran (Wadhams et al., 2021). The new administration has also eased restrictions on the movement of Iranian diplomats in New York imposed by the Trump administration in 2019 (Haboush, 2021). Indicating U.S. awareness of the importance of linkages in diplomatic initiatives, the latest American overtures were initiated at the same time as the first visit of UN special envoy to Yemen, Martin Griffiths, on 7 February 2021, to Iran to win Iran's support for a political solution to the ongoing war in Yemen. As a result of the Biden Administration's manoeuvres, negotiations have resumed and indirect U.S.-Iran talk has started with the intentions to reactivate the deal before June prior to the Iranian presidential election.

\section{The War in Yemen}

The relationship of the Yemen war to the stability of the Gulf region is a complex one. The importance of Yemen for the Gulf states and particularly Saudi Arabia stems from the followings: 1) Yemen's geostrategic location controlling the flow of maritime traffic in the Red Sea through Bab el-Mandeb; 2) the contentious issue of the Saudi-Yemeni border with the Yemenis seeing the border agreement as unfair; 3) the potentially destabilizing influence of Yemenis decampment to the Gulf states and settlement in both Saudi Arabia and the UAE; 4) the Saudis perception of Yemen as the bulwark for its southern security. For these reasons, Saudi Arabia and the UAE are engaged in a proxy war with Iran in Yemen. The war has impacted regional security particularly Saudi national security. At the same time, the new Democratic administration is reviewing U.S. foreign policy priorities in the region, giving more weight to the American values and interests. Joe Biden has repeatedly expressed a desire to end the human disaster in Yemen through ending U.S. support to Gulf allies for execution of the war. The new approach coincides with reviving Barak Obama's policy of shifting priority for U.S. involvement from the Middle East to South East Asia. This new

${ }^{11}$ The Guardian (2021, February 7). Biden will not lift sanctions to get Iran back to negotiating table. The Guardian.

https://www.theguardian.com/us-news/2021/feb/07/biden-iran-sanctions-negotiating-table-nucleardeal.

${ }^{12}$ Reuters (2021, February 11). Minister says Qatar working for return to Iran nuclear accord: report. Reuters. https://www.reuters.com/article/us-usa-iran-nuclear-qatar-idUSKBN2AB0I0. 
thinking in U.S. foreign policy towards the Gulf demands constructive collective engagement of Gulf countries to maintain Gulf security and stability. Such collaboration cannot be achieved unless major contentious issues are addressed, including the war in Yemen.

Moral considerations have tended not to play a significant role in foreign policy undertakings, especially when national interests are narrowly defined. Foreign policy choices can involve arms sales to authoritarian regimes that are allies (Nye, 2020: p. 41) while simultaneously criticizing the human rights records of such allies ${ }^{13}$. The U.S. position on the war in Yemen clearly illustrates such a contradictory policy. On the one hand, the U.S. criticizes the interminable war and human suffering in Yemen. On the other hand, the U.S., until recently, provided technical and intelligence support and approved arms sales to its allies involved in that war. In May 2019, Trump did not hesitate to use his emergency authority to bypass Congress objections and sell the Saudi's $\$ 86$ billion in arms (Woodward, 2020: p. 227). This action reflects a disjuncture between intentions and actions. However, in this case, the differing intentions and actions involved two branches of the U.S. government, with the legislative branch wanting to pressure Saudi Arabia whereas the executive branch supported continued military action.

On 26 March 2015, Saudi Arabia began and led a military operation, Operation Decisive Storm, against the Houthis in Yemen. MBS ordered U.S.-made F15 jet fighters to engage in what was to become a prolonged war. Saudi generals have expressed concerns about becoming involved in a situation that would be a "quagmire for any foreign power for a century" (Hope \& Scheck, 2020: p. 29). Blinken, when previously serving under the Obama administration, was dispatched to Riyadh to meet the then Crown Prince Mohamed Bin Nayef (MBN), who seemed dismissive, with Blinken claiming that "MBS hadn't even consulted with MBN" (Hope \& Scheck, 2020: p. 31). Prince Ahmed Bin Abdul-Aziz, a potential contender to the throne, stated to protesters in London, in September 2018: “don't blame the Al Saud, the bombing is the responsibility of just two men the King and the Crown Prince" (Hope \& Scheck, 2020: p. 329).

In contrast to their normally sharply differing approaches, U.S. administrations under Obama and Trump both approved the Saudi-led coalition war in Yemen. Obama gave the war his qualified approval, in part to assuage Saudi anger over the Iran nuclear deal in 2015 (Sanger \& Schmitt, 2021), and "authorized the provision of logistic intelligence support to GCC-led military operations" (Zenko, 2015). National Security Council Spokesperson, Bernadette Meehan, stated that "we established a joint planning cell with Saudi Arabia to coordinate U.S. military intelligence support” (Zenko, 2015).

The war in Yemen, from March 2015 to January 2021 (and ongoing), has brought about much destruction and human suffering. The UN Security Council issued Resolution No. 2216 (2015) on the situation in Yemen. Trump, under

\footnotetext{
${ }^{13}$ Saudi Arabia and Egypt are major arms importers from the U.S. while being constantly criticized
} by the U.S State Department concerning their respective human rights records. 
significant pressure from Congress, decided in 2018 to halt aerial refuelling of Saudi jets engaged against the Houthis. The only military support still provided was U.S. training of Saudi personnel and intelligence sharing focused on Houthi threats against the Kingdom (Gearan et al., 2021). The question now arises as to how the Biden administration will deal with the war in Yemen. Biden has vowed to recalibrate relations with Saudi Arabia and end support for the war in Yemen. Blinken confirmed that the new administration would stop all forms of support to the Saudi military campaign in Yemen. The new balanced foreign policy approach has become clear in Biden's criticism of Saudi war efforts, promising to treat its leaders as "the pariah that they are' and to take away the Kingdom's "dangerous carte blanches" (Sanger, 2021). Blinken has also spoken bluntly concerning Saudi culpability in the Yemen War (Borger \& Wintour, 2021), as well blaming the Saudis for the human suffering in a country already on the brink of famine (Usher, 2021a). At the same time, Blinken condemned acts of aggression by Houthi militias against the U.S.'s partner Saudi Arabia (Salama, 2021b) and expressed concerns regarding Houthi drone and missile attacks against Saudi Arabia. On the other hand, Blinken later revoked the designation of the Houthis as terrorists, thus removing an obstacle jeopardizing the delivery of crucial aid to millions of displaced people (Blinken, 2021). In a further step, the Biden administration halted, pending review, F-35 jet sales (Usher, 2021a) to the UAE worth $\$ 23.4$ billion that Trump had authorized as part of a package of advanced defence equipment ${ }^{14}$. The move was taken to help ensure that the war in Yemen would not be prolonged. However, the UAE Ambassador to the U.S., Al-Otaiba, predicted that the halt would be temporary, and that the deal would eventually proceed $^{15}$. Indeed, having weighed the U.S. interest in advancing the arms deal with the UAE, Biden's administration has now informed Congress that it is proceeding with the sale, including advance F-35 aircraft, armed drones and other equipment to the UAE (Mehta, 2021). The Biden administration has also frozen the sale of 3000 precision-guided munitions worth $\$ 478$ million to Saudi Arabia (Naar, 2021). Additionally, the U.S. has ended the provision of targeting data and logistical support to the Saudis for Yemeni operations. This reversal of policy in relation to previous American support for the Saudi war effort, which dated from the Obama administration and notwithstanding Biden's role in helping formulate that original support, is a clear signal of the Biden administration's recalibration of support to the Gulf states, and a change of policy from the Obama administration. In another signal, on 2 February 2021, Biden reversed Trump's decision to grant the UAE most favoured nation status as a trading partner, a move that would have exempted the UAE's aluminium imports from the 10 percent custom tariffs that went into effect on 3 February 2021 (Leonard \& Deaux, 2021).

\footnotetext{
${ }^{14}$ The package includes up to $50 \mathrm{~F}-35$ s Lightning II fighter jets, valued at $\$ 10.46$, up to $18 \mathrm{MQ}-9 \mathrm{~B}$ unmanned aerial systems (advanced armed drone systems), valued at $\$ 2.76$ billion, and air-to-air and air-to-ground weaponry valued at $\$ 10$ billion.

${ }^{15}$ Reuters (2021, February 2). UAE confident F-35 jets sale will go through, says ambassador. Reuters. https://www.reuters.com/article/usa-emirates-f35-int-idUSKBN2A20LC.
} 
Riyadh insists that it wants to end what now seems a mistaken war, but with Houthi rockets, possibly supplied by Iran, falling on Saudi Arabia, it has no option but to resist. The Houthi militia have fired ballistic missiles onto Saudi territory including those with a range of $1000 \mathrm{~km}$. The Iranian connection in Yemen is not clear, but there are multiple indicators that point to Iranian involvement. Rivalry between Saudi Arabia and Iran has affected various regions in which proxy wars are being fought, especially Yemen (Mezran \& Vavelli, 2019, p. 10). The Biden administration faces the task of applying pressure for a negotiated settlement to the war in Yemen, while still providing security assurances to its Gulf allies. In his first foreign policy speech at the U.S. State Department, Biden reiterated his commitment to help defend Saudi Arabia. However, in naming Timothy Lenderking as the U.S. special envoy for Yemen, Biden explicitly served notice that he will put more pressure on the warring parties to negotiate a peace agreement (Borger \& Wintour, 2021).

Saudi Arabia has welcomed the initiative to end the war in Yemen. Khalid bin Salman, the Saudi Deputy Defence Minister, tweeted on 5 February 2021 in praise of Biden's commitment to work with friends and allies to resolve conflicts and deal with attacks from Iran and its proxies in the region: "As we have for over seven decades, we look forward to working with our friends in the U.S. on addressing these challenges" (Salman, 2021). The UAE government has also expressed its commitment to back Biden's call to end the war. The UAE withdrew its forces from Yemen in October 2020, with any forces left behind forming part of an Arab coalition (Salama, 2021a). Saudi Foreign Minister, Faisal bin Farhan, has stated: "We look forward to working with Tim Lenderking to achieve our joint goal of a comprehensive political resolution in Yemen as part of our shared vision for a peaceful and prosperous region" (Brennan, 2021). According to Mick Mulroy, former CIA and ABC News analyst, "there needs to be a comprehensive international plan, preferably led by the U.S., to support the UN in achieving a lasting peace" 16 . The Biden administration expects the U.S.'s European allies to follow its lead in helping to bring an end to the humanitarian crisis in Yemen. Italy, following the U.S. move, decided to halt the sale of 20,000 missiles to Saudi Arabia and the UAE, worth $\$ 450$ million, as part of Rome's commitment to peace in Yemen and respect for human rights ${ }^{17}$. The U.S. move places pressure on its other allies to review their arms sales to the region. The success of the U.S. policy in ending the war in Yemen will, however, depend on progress made concerning the Iran nuclear deal and the constructive engagement of Gulf countries in institutionalizing intra-Gulf dialogue to create long-lasting security arrangements.

The research findings can be summarized as follows:

${ }^{16}$ The Reuters (2021, January 29). Italy blocks sale of missiles to Saudi Arabia and UAE. Reuters. https://www.reuters.com/article/us-yemen-security-gulf-italy-idUSKBN29Y1VV.

${ }^{17}$ Seeing 2020 (February 4, 2021). U.S. ending support for Saudi-led war in Yemen as Biden shifts foreign policy.

http://seeing2020.us/u-s-ending-support-for-saudi-led-war-in-yemen-as-biden-shifts-foreign-policypriorities/ 
1) President Biden is disassociating himself from former President Trump's retrenchment approach to foreign policy.

2) The Biden administration can be expected to adopt Obama's approach of shifting priorities away from the contentious Middle East region to South East Asia, to confront new emerging challenges, making the Gulf states less of a U.S. priority. However, a scaling down in terms of importance does not entail a complete withdrawal from the region.

3) The Gulf region will continue to have geostrategic importance in U.S. global foreign policy undertakings.

4) Biden has initiated a foreign policy that differs from Obama's foreign policy in that it is more prepared to weigh American values against the interests of its Arab Gulf allies.

5) The new thinking includes a return to globalization but with an understanding that the U.S. will be less inclined to pursue unilateral action or use force to deal with foreign policy challenges.

6) The analysis conducted in this study has shown that, despite the pitfalls of the Trump legacy, the Biden administration is more inclined to pursue a foreign policy with as broad a base of domestic support as the currently polarized political scene allows, based on a critical macro-level assessment of U.S. values and national interests.

7) Given this context, the U.S. will continue to play a leading global role, based on the principle of engagement with allies and partners, and of continued dialogue with specific emerging independent regional/global actors.

\section{Conclusion}

The comparative analysis of the Biden's Administration foreign policy in the first 100-Days reveals a fundamental shift from Donald Trump's foreign policy orientations and a clear difference from the previous republican administrations. The new administration has adopted a closer foreign policy posture to the previous democratic administrations but did not hesitate to pursue different approach on certain issues weighing more on the American values and interests. Biden's administration, for example, pursued a policy that differs with the Obama's Administration foreign policy to which he was a member as is the case towards the war in Yemen. Biden has promised an engaged foreign policy that will operate on a democratic-progressive basis. The reasons behind that are many, however, the Biden's personal experience and perception of world affairs, the role of the professional governing technocrats, and the influence of the democratic left who brought him to power are the paramount.

The U.S. is likely to encourage more international involvement from its partners in support of initiatives to engage the Gulf countries in constructive dialogue. Potentially constructive initiatives could include supporting de-escalation talks between Arab Gulf monarchies and Iran and a diplomatic effort involving other international powers to establish a regional security forum in the Middle East similar to the Organization for Security and Co-operation in Europe (Kaye 
et al., 2021). In pursuing the objective of preventing Iran from becoming a nuclear power, the Biden administration is prepared to revitalize the $5+1$ negotiations to ultimately secure a full commitment to a nuclear deal with Iran. This rethinking of the U.S.-Saudi Arabia relationship and constraining pressure placed on MBS can be expected to yield significant outcomes, including an end to the war in Yemen, release of political prisoners, and a more rational Saudi foreign policy.

In conclusion, a principled U.S. foreign policy towards the Gulf under the Biden administration will require a revitalized global engagement on the part of the U.S. government. Only with the collaboration of allies in the region and around the world will the U.S. be able to pursue the multiple initiatives needed to address the legitimate security concerns of the Arab Gulf states while advancing human rights. In successfully pursuing these initiatives, U.S. leaders will need to recognize the interrelationships among the initiatives and be able to pursue them in parallel, demonstrating an understanding of cultural differences that contribute to conflict. To have the political space to maintain the focus needed to advance these Gulf initiatives, Biden and his team will also need early wins in advancing his domestic agenda. Clearly, the challenges facing Biden are daunting, but in finding the energy and commitment to emerge from retirement to seek the U.S. presidency in the face of monumental crises, he has demonstrated that he is highly capable.

\section{Conflicts of Interest}

The author declares no conflicts of interest regarding the publication of this paper.

\section{References}

Abozaid, A. M. (2020). The Rise of Small States in the Arabian Gulf: The Case of UAE and Qatar. Journal of Rising Powers and Global Governance, 1, 7-41.

Al Sawafi, M. K. (2021). A Gulf Perspective on Biden's Middle East Orientations. Policy Paper, No. 19. http://www.trendsresearch.org

AlAlkim, H. (1994). The GCC States in an Unstable World. London: Saqi Books.

Barnes, J. E. (2021, Published March 16, Updated May 27). Putin Ordered 2020 Election Meddling. The New York Times. https://www.nytimes.com/2021/03/16/us/politics/election-interference-russia-2020-ass essment.html

Bayoumy, Y. (2016, September 7). Obama Administration Arms Sales Offers to Saudi Top $\$ 115$ Billion: Report. Reuters. https://www.reuters.com/article/us-usa-saudi-security-idUSKCN11D2JQ

Beech, H. (2020, November 30). “Trump Is Better”: In Asia, Pro-Democracy Forces Worry about Biden. The New York Times. https://www.nytimes.com/2020/11/30/world/asia/biden-trump-china-asia.html

Blinken, A. (2021, February 12). Revocation of the Terrorist Designations of Ansarallah. Press Statement.

https://www.state.gov/revocation-of-the-terrorist-designations-of-ansarallah/ 
Borger, J., \& Wintour, P. (2021, February 4). Biden Announces End to US Support for Saudi-Led Offensive in Yemen. The Guardian.

https://www.theguardian.com/world/2021/feb/04/us-end-support-saudi-led-operations -yemen-humanitarian-crisis

Brennan, D. (2021, February 5). Saudi Arabia Skips over Joe Biden Ending U.S. Support in Yemen War. Newsweek.

https://www.newsweek.com/saudi-arabia-skips-over-joe-biden-ending-us-support-ye $\underline{\text { men-war-1567057 }}$

Bureau of Labor Statistics (2021, February 5). The Employment Situation-January 2021. https://www.bls.gov/news.release/archives/empsit 03052021.pdf

Burns, D. (2021, January 9). Trump Ends His Term Like a Growing Number of Americans: Out of a Job. Reuters.

https://www.reuters.com/article/us-usa-economy-trump-idUSKBN29D30I

Congressional Research Service (CRS) (2020, November 23). Arms Sales in the Middle East: Trends and analytical Perspectives for U.S. Policy. https://fas.org/sgp/crs/mideast/R44984.pdf

Crowley, M. (2021, February 4). Biden Announces the End of U.S. Support to Saudi War in Yemen. The New York Times.

https://www.nytimes.com/2021/02/04/us/biden-yemen-saudi-arabia.html

Dorsey, J. (2017, November 20). Transition in the Middle East: Transition to What? https://mideastsoccer.blogspot.com/2017/11/transition-in-middle-east-transition-to.ht $\underline{\mathrm{ml}}$

Dorsey, J. (2021, February 8). Separating the Wheat from the Chaff: Saudi Moderation Put to the Test. Modern Diplomacy. https://moderndiplomacy.eu/2021/02/08/separating-the-wheat-from-the-chaff-saudimoderation-put-to-the-test/

Fabian, J., Jacobs, J., \& Wainer, D. (2021, February 16). Biden Downgrades Saudi Crown Prince to "Recalibrate" Ties. Bloomberg.

https://www.bloomberg.com/news/articles/2021-02-16/biden-to-recalibrate-saudi-arab ia-ties-away-from-crown-prince

Fassihi, F., Sanger, D. E., Schmitt, E., \& Bergreen, R. (2020, December 9). Iran Top Nuclear Scientist Killed in Ambush. The New York Times.

https://www.nytimes.com/2020/11/27/world/middleeast/iran-nuclear-scientist-assassin ated-mohsen-fakhrizadeh.html

Gardner, F. (2021, February 1). Saudi Human Rights under New Spotlight in Biden Era. BBC News. https://www.bbc.com/news/world-middle-east-55794286

Gearan, A., Ryan, M., \& Hudson, J. (2021, February 4). Biden Recommits U.S. to Global Alliances, Ends Support for Saudi-Led War in Yemen in First Major Foreign Policy Speech. The Seattle Times.

https://www.seattletimes.com/nation-world/biden-recommits-u-s-to-global-alliances-e nds-support-for-saudi-led-war-in-yemen/

Ghantous, G. (2021, May 7). Iran-Saudi Arabia Relations. Republic World. https://www.reuters.com/world/middle-east/saudi-official-confirms-talks-with-iran-sa ys-premature-assess-outcome-2021-05-07/

Haass, R. (2021, February 27). A Realist Rest for US-Saudi Relations. Project Syndicate. https://www.project-syndicate.org/commentary/us-saudi-relations-after-khashoggi-int elligence-report-by-richard-haass-2021-02?barrier=accesspaylog

Haboush, J. (2021, February 3). Iran Is a "Far Cry" Away from Returning to JCPOA Commitments: US State Department. Al-Arabiya. 
https://english.alarabiya.net/News/world/2021/02/03/Iran-is-a-far-cry-away-from-retu rning-to-JCPOA-commitments-US-State-Department

Hope, B., \& Scheck, J. (2020). Blood \& Oil: MBS's Ruthless Quest for Global Power. New York: Hachette Books.

Inbari, M., Bumin, K. M., \& Byrd, M. G. (2021). Why Do Evangelicals Support Israel? Politics and Religion, 14, 1-36.

https://www.cambridge.org/core/journals/politics-and-religion/article/abs/why-do-eva ngelicals-support-israel/F8AB8C41F0B019FD8413A30EF218EBE4 https://doi.org/10.1017/S175504831900052X

Jakes, L., Ismay, J., \& Myers, S. L. (2021, March 14). Biden Goals Converge in Asia: Rebuilding Alliances and Countering China. The New York Times. https://www.thetimereports.com/2021/03/news-from-time-reportsbiden-goals.html

Karni, A., Tankersley, J., \& Cochrane, E. (2021). Confirmation in Doubt for Neera Tanden, Biden's Budget Director Pick. The New York Times. https://www.nytimes.com/2021/02/25/business/neera-tanden-confirmation.html

Kaye, D. D., Robinson, L., Martini, J., Vest, N., \& Rhoades, A. L. (2021). Reimagining the Middle East, Executive Summary. Santa Monica, CA: Rand Corporation. https://www.rand.org/pubs/research reports/RRA958-1.html

Kempe, F. (2021, February 20). Biden Sought to Rally U.S. Allies in Munich, but Unity Will Prove Difficult as China's Influence Grows. $C N B C$.

https://www.cnbc.com/2021/02/20/op-ed-biden-sought-to-rally-allies-in-munich-as-ch ina-influence-grows.html

King Abdullah Petroleum Studies and Research Center (KAPSARC) (2018). Data Insight, Annual Proven Crude Oil Reserves, December. OPEC Annual Bulletin.

Koetti, C. (2020, December 9). Iran Is Moving Key Facility at Nuclear Site Underground. The New York Times. https://www.nytimes.com/2020/12/09/world/natanz-nuclear-facility-iran.html

Lee, M. (2021, January 29). Biden Presses Iran Diplomacy as New Special Envoy Tapped. Associated Press. https://apnews.com/article/joe-biden-donald-trump-biden-cabinet-antony-blinken-ira n-7abac9eafa91c9250f42a228bff38fe0

Lendon, B. (2021, March 11). Quad Alliance of US, Japan, India and Australia Is Part of Biden's Plan to Contain China. CNN.

https://edition.cnn.com/2021/03/11/asia/quad-us-india-japan-australia-intl-hnk/index. $\underline{\mathrm{html}}$

Leonard, J., \& Deaux, J. (2021, February 2). Biden Overrules Trump on UAE Tariff, Keeping Aluminium Duties. Bloomberg.

https://www.bloomberg.com/news/articles/2021-02-02/biden-overrules-trump-on-uaetariff-keeping-aluminum-duties

Mehta, A. (2021, April 15). Biden Admin Moving Ahead with UAE F-35, Drone Sales for Now. Defense News.

https://www.defensenews.com/global/mideast-africa/2021/01/08/uae-f-35-contracts-ex pected-to-be-signed-before-end-of-trump-admin/

Mezran, K., \& Varvelli, A. (Eds.) (2019). The Mina Region: A Greater Power Competition. Milano: LedozioniLedi Publishing (published by ISPI \& Atlantic Council).

Morgenthau, H. (1973). Politics among Nations: The Struggle for Power and Peace (5th ed.). New York: Alfred A Knopf.

Murphy, F. (2021, February 10). Iran Produces Uranium Metal IAEA Says. Reuters. 
https://www.reuters.com/article/iran-nuclear-iaea-int-idUSKBN2AA2LW

Naar, I. (2021, February 27). US Wants Change but Not "Rupture" with Saudi Arabia: Blinken. Al Arabyia.

https://english.alarabiya.net/News/world/2021/02/27/US-foreign-policy-US-wants-cha nge-but-not-rupture-with-Saudi-Arabia-Blinken

Nakashima, E., \& Dawsey, J. (2020). Trump Contradicts Pompeo in Bid to Downplay Massive Hack of U.S. Government Russia's Role. The Washington Post.

https://www.washingtonpost.com/national-security/russia-is-behind-the-broad-ongoin g-cyber-spy-campaign-against-the-us-government-and-private-sector-pompeo-says/20 20/12/19/8c850cf0-41b3-11eb-8bc0-ae155bee4aff story.html

Nye, J. S. (2020). Do Morals Matter? Presidents and Foreign Policy from FDR to Trump. New York: Oxford Press.

O’Sullivan, D., \& Cohen, Z. (2020, September 10). Russian, Chinese and Iranian Hackers All Targeting 2020 Election, Microsoft Says. CNN.

https://edition.cnn.com/2020/09/10/politics/microsoft-election-hacking-report/index.h $\underline{\mathrm{tml}}$

Obama, B. (2020). A Promised Land. Crown.

Parsi, T. (2021). Toward an Inclusive Security Arrangement in the Persian Gulf. Quincy Brief No. 7, Quincy Institute for Responsible Statecraft.

Paton, E. (2021, January 25). China Overtakes the U.S. as the Top Destination for Foreign Investment. The New York Times. https://www.nytimes.com/live/2021/01/25/business/us-economy-coronavirus\#chinaov ertakes-the-us-as-the-top-destination-for-foreign-direct-investment

Porterfield, C. (2021, February 4). Biden Says He Won't Let the U.S. Continue “Rollin over" for Russia, Like Trump Did. Forbes.

https://www.forbes.com/sites/carlieporterfield/2021/02/04/biden-says-he-wont-let-theus-continue-rolling-over-for-russia-like-trump-did/?sh=5f8a111f30 9

Price, N. (2021, February 2). Press Briefing.

https://www.state.gov/briefings/department-press-briefing-february-2-2021/

Ross, D., \& Satloff, R. (2021). Defining a Mature, Balanced Relationship with Saudi Arabia: An Urgent Task for the Biden Administration (Policy Notes 6). Washington Institute for Near East Policy, February 22.

https://www.washingtoninstitute.org/policy-analysis/defining-mature-balanced-relatio nship-saudi-arabia-urgent-task-biden-administration

Sager, A., \& Mousavian, H. (2021, January 31). We Can Escape a Zero-Sum Struggle between Iran and Saudi Arabia. The Guardian.

https://www.theguardian.com/commentisfree/2021/jan/31/iran-saudi-arabia-joe-biden -cooperation

Salama, S. (2021a, February 8). UAE to Celebrate Return of Its Heroes from Yemen. Gulf News.

https://gulfnews.com/uae/government/uae-to-celebrate-return-of-its-heroes-from-yem en-on-sunday-1.1581173409562

Salama, S. (2021b, January 28). US Secretary of State Antony Blinken Targets Al Houthis. Gulf News.

https:/gulfnews.com/world/gulf/yemen/us-secretary-of-state-antony-blinken-targets-a l-houthis-1.76785286

Salman, K. (2021). https://twitter.com/kbsalsaud/status/1357459673226567680

Sanger, D. E. (2021, February 24). Candidate Biden Called Saudi Arabia a "Pariah." He 
Now Has to Deal with It. The New York Times.

https://www.nytimes.com/2021/02/24/us/politics/biden-jamal-khashoggi-saudi-arabia. $\underline{\mathrm{html}}$

Sanger, D., \& Schmitt, E. (2021, February 4). Biden Signals Break with Trump Foreign Policy. The New York Times.

https://www.nytimes.com/2021/02/04/us/politics/biden-foreign-policy.html

Sargent, G. (2020, November 30). Mitch McConnell's Ability to Cripple Biden's Presidency Depends on One Thing. The Washington Post.

https://www.washingtonpost.com/opinions/2020/11/30/mitch-mcconnells-ability-crip ple-bidens-presidency-depends-one-thing/

Securing America's Future Energy (SAFE) (2018, September 21). The Military Cost of Defending Global Oil Supply. Issue Brief, SAFE.

http://secureenergy.org/wp-content/uploads/2020/03/Military-Cost-of-Defending-theGlobal-Oil-Supply.-Sep.-18.-2018.pdf

Shesgreen, D. (2021, February 28). Saudi Arabia's Mohammed Bin Salman Complicit in Jamal Khashoggi's Murder, US Report Says. Yahoo.

https://currently.att.yahoo.com/att/saudi-arabias-mohammad-bin-salman-183753010. $\underline{\mathrm{htm}}$

Sink, J. (2021, January 29). Biden Adviser Warns of "Escalating Nuclear Crisis" with Iran. Bloomberg.

https://www.bloomberg.com/news/articles/2021-01-29/biden-adviser-warns-of-escalati ng-nuclear-crisis-with-iran

Stockholm International Peace Research Institute (SIPRI) (2020, March 9). USA and France Dramatically Increase Major Arms Exports; Saudi Arabia Is Largest Arms Importer. SIPRI.

https://www.sipri.org/media/press-release/2020/usa-and-france-dramatically-increasemajor-arms-exports-saudi-arabia-largest-arms-importer-says

Strobel, Wa. (2020, March 30). Saudi Arabia Invites Houthi Rebels to Talk in Riyadh. The Wall Street Journal.

https://www.wsj.com/articles/saudi-arabia-invites-houthi-rebels-to-talks-in-riyadh-115 85616096/

Tenpas, K. D. (2021). Tracking Turnover in the Trump Administration. Brookings Report.

https://www.brookings.edu/research/tracking-turnover-in-the-trump-administration/

Troianovski, A. (2021, March 18). Russia Erupts in Fury over Biden's Calling Putin a Killer. New York Times.

https://www.nytimes.com/2021/03/18/world/europe/russia-biden-putin-killer.html

Turak, N. (2021, February 17). Biden's Snub of Saudi Crown Prince Mohammed bin Salman Is a "Warning" Signalling a Relationship Downgrade. $C N B C$.

https://www.cnbc.com/2021/02/17/bidens-snub-of-saudi-crown-prince-mohammed-bi n-salman-is-a-warning.html

U.S. Department of State (2021, January 20). Iran Sanctions. U.S. Department of State. https://www.state.gov/iran-sanctions/

Usher, B. P. (2021a, January 28). Antony Blinken: Who Is America's New Top Diplomat? $B B C$. https://www.bbc.com/news/world-us-canada-55836461

Usher, B. P. (2021b, March 17). What the US Really Wants from the China Talks. $B B C$. https://www.bbc.com/news/world-us-canada-56423036?xtor=AL-72-\%5Bpartner\%5D\%5Bmicrosoft \%5D-\%5Bheadline\%5D-\%5Bnews\%5D-\%5Bbizdev\%5D-\%5Bisapi\%5D

Wadhams, N., Motevali, G., \& Tirona, J. (2021, February 6). Biden Weighs Easing Iran’s 
Pain. Bloomberg.

https://www.bloomberg.com/news/articles/2021-02-06/biden-weighs-easing-iran-s-pai n-without-lifting-key-sanctions

Wechsler, W. F. (2019). US Withdrawal from the Middle East: Perceptions and Reality. In K. Mezran, \& A. Varvelli (Eds.), The MENA Region: A Greater Power Competition. Ledizioni Ledi Publishing by ISPI \& Atlantic Council.

Wehner, P. (2021, January 22). The End of Trump Can Be the Beginning of America. The New York Times. https://www.nytimes.com/2021/01/22/opinion/trump-legacy.html

Wintour, P. (2021, January 31). Biden Presidency "May Herald New Start for Saudi-Iranian Relations". The Guardian, 31 January.

https://www.theguardian.com/world/2021/jan/31/biden-presidency-spell-new-start-sa udi-iranian-relations

Woodward, B. (2020). Rage. New York: Simon \& Schuster.

Zenko, Mi. (2015). Obama's War of Choice: Supporting the Saudi-Led Air War in Yemen. Council on Foreign Relations.

https://www.cfr.org/blog/obamas-war-choice-supporting-saudi-led-air-war-yemen 